\title{
KESEDARAN RISIKO DAN TINGKAHLAKU SELAMAT “ALTRUISTIC” DALAM AKTIVITI REKREASI PROGRAM BINA INSAN GURU
}

\author{
Muhammad Syakir Sulaiman, M. Adli Mohd Sidi, Mohd Salihin Hafizi Mohd Fauzi \& Julia \\ Mazlan
}

\author{
Kolej Universiti Islam Antarabangsa Selangor, Malaysia \\ Universiti Tun Abdul Razak, Malaysia
}

Jurnal Sains Sukan dan Pendidikan Jasmani 8(1) 31-38, Received: 20 Mei 2019, Accepted: 17 Jun 2019

DOI: https://doi.org/10.37134/jsspj.vol8.1.4.2019

\begin{abstract}
Abstrak
Kajian ini bertujuan untuk mengenalpasti dan membandingkan tahap kesedaran risiko dan tingkahlaku selamat "altruistic" antara jantina di samping mengkaji hubungan antara keduanya dalam kalangan para peserta semasa aktiviti rekreasi dalam Program Bina Insan Guru (BIG). Satu set soal selidik telah digunakan terhadap seramai 81 pelajar tahun akhir Fakulti Pendidikan, KUIS di Raub, Pahang. Soal selidik terdiri daripada dua pembolehubah, iaitu kesedaran terhadap risiko dan tingkah laku keselamatan. Hasil kajian menunjukkan kesedaran yang tinggi tentang risiko semasa aktiviti rekreasi. Analisis ujian T menunjukkan tidak terdapat perbezaan yang signifikan dalam kesedaran risiko dan tingkah laku keselamatan antara jantina. Analisis korelasi Pearson menunjukkan bahawa terdapat hubungan positif yang signifikan antara kesedaran risiko (peraturan keselamatan) dan tingkahlaku keselamatan "altruistic". Implikasi kajian ini adalah pengurus rekreasi dan universiti perlu mengambil kira kepelbagaian jenis risiko dalam merancang aktiviti rekreasi luaran. Tahap kesedaran risiko yang tinggi dapat membantu pelajar dengan tingkah laku yang baik dalam aktiviti rekreasi luar yang mereka ceburi.
\end{abstract}

Kata kunci: Jantina, Kesedaran risiko, Tingkahlaku keselamatan

\section{RISK AWARENESS AND ALTRUISTIC SAFE BEHAVIOUR IN RECREATIONAL ACTIVITIES DURING TEACHER SELF-BUILDING PROGRAM}

\begin{abstract}
This study aimed to determine and compare risk awareness and altruistic safe behavior between genders and the relationship between both among participants during recreational activity in the Teacher Self-Building Program. A set of questionnaire was used as a survey tool on 81 final year students of the Faculty of Education, KUIS at Raub, Pahang. The questionnaire consisted of two variables, namely, awareness of risk and safety behavior. The findings showed high awareness of risks during recreational activities. T-test analysis showed that there was no significant difference in the risks awareness and safety behaviors between genders. Pearson correlation analysis showed that there is a significant positive relationship between risk awareness (safety rules) and safety behavior (altruism). Implications of this research are recreation managers and the university need to take into account the diversity of risks in planning outdoor recreational activities. A high level of risk awareness can help students with good behavior in outdoor recreation activities
\end{abstract}

Keywords: gender, risk awareness, safety behavior. 


\section{PENGENALAN}

Kesedaran terhadap aspek keselamatan amat penting bagi mengelakkan berlakunya kemalangan terutamanya di dalam aktiviti rekreasi. Ini kerana di tempat rekreasi terdapat pelbagai ancaman yang berbahaya. Oleh itu, apabila berada di tempat rekreasi perlulah menjaga keselamatan dan mengikut prosedur dan piawaian keselamatan yang telah ditetapkan. Prosedur keselamatan ini perlu ditekankan sebagai salah satu bahagian yang penting dalam program aktiviti rekreasi luar pendidikan di institut pengajian tinggi di Malaysia. Dengan adanya prosedur tersebut, ia dapat memberi peserta sedikit pengetahuan dan boleh diaplikasikan di luar khusus dalam melakukan aktiviti lasak yang berisiko. Melalui penglibatan aktiviti rekreasi luar dapat memberikan kesan yang positif terhadap individu seperti menambah ilmu pengetahuan, meningkatkan kemahiran dan juga kecergasan (Noor \& Mohamad, 2002). Tribe (2011) menyatakan bahawa aktiviti rekreasi boleh ditakrifkan sebagai melakukan aktiviti riadah semasa masa lapang dan ianya juga merangkumi aktiviti yang sangat berbeza seperti berkayak, memancing, mendaki gunung dan lain-lain. Keselamatan amat berkait rapat dengan persekitaran hidup dan isu keselamatan penting terutama melibatkan aktiviti rekreasi luar baik laut atau darat. Keselamatan adalah satu keadaan sifar bahaya, tiada peluang yang boleh mewujudkan suasana bahaya (Holt \& Lampl, 2005).

Penggunaan aktiviti rekreasi air dan darat semakin meningkat dalam kebanyakkan program latihan kemahiran insaniah di institut pengajian tinggi awam dan sewasta. Pemilihan aktiviti tersebut adalah kerana aktiviti lasak ini dapat menguji kemampuan mental dan fizikal seluruh badan disamping ia dapat memberi manfaat kepada kesihatan. Penglibatan dalam aktiviti rekreasi juga sering dikaitkan dengan risiko kemalangan, seperti kecederaan, sesat, panik, dihanyut arus dan kayak terbalik dalam aktiviti rekreasi yang disertai. Isu keselamatan merupakan perkara utama yang dititik beratkan oleh mana-mana pihak pengurus syarikat atau jabatan pentadbiran. Kemungkinan berlaku kesan risiko ini mengakibatkan perlunya untuk mewujudkan garis panduan yang boleh ditukar kepada standard yang bersesuaian sama ada aktiviti rekreasi darat atau air. Pengurusan risiko yang berkesan dapat memastikan persekitaran yang selamat, sihat dan estetik serta menyenangkan kepada mereka yang terlibat. Tindakan oleh pihak pengurusan yang mempunyai kepakaran mungkin diperlukan untuk memastikan persekitaran aktiviti rekreasi yang selamat termasuk pematuhan dan langkah penguatkuasaan, perlaksanaan kawalan, kesedaran diri, inisiatif maklumat dan nasihat dalam rangka kerja pengurusan keselamatan dalam aktiviti rekreasi yang disediakan.

\section{Teori kemalangan}

Menurut teori kemalangan Petersen, (Zakaria, Harun, Salamuddin \& Taff, 2016) kelemahan pengurusan aspek keselamatan adalah punca kepada berlakunya kemalangan. Antara kelemahan pengurusan aspek keselamatan adalah seperti ketiadaan prosedur risiko dan keselamatan, tidak jelas tentang tanggungjawab dan peraturan keselamatan, latihan teknikal yang tidak mencukupi dan sebagainya. Oleh itu kesedaran berkaitan keselamatan perlu diambil oleh pengurusan tempat rekreasi. Garis panduan disyorkan untuk beberapa keadaan persekitaran terhadap risiko kemalangan dan bahaya yang terdedah kepada orang ramai dalam aktiviti rekreasi. Garis panduan merangkumi beberapa aspek seperti mengenalpasti tingkahlaku peserta, penggunaan peraturan keselamatan dengan menyesuaikan beberapa garis panduan lain yang sesuai dengan keadaan setempat.

Garis panduan yang dimaksudkan adalah perlaksanaan peraturan keselamatan yang digunakan bertujuan bagi memastikan kesedaran individu berkaitan bahaya di tempat rekreasi. Peraturan keselamatan dapat memberikan kesedaran terhadap tingkahlaku selamat individu bagi memastikan keselamatan dan kesihatan di tempat rekreasi terhadap diri dan orang lain yang terdedah dengan risiko dan bahaya. Penggiat rekreasi dan orang awam mestilah mematuhi peraturan dan garis panduan yang relevan "sekurang-kuranganya mengekalkan keselamatan yang setara baik" serta mengikuti amalan terbaik dan nasihat yang diberikan. Peraturan keselamatan mampu membentuk satu sistem kawalan pengurusan keselamatan semasa aktiviti beroperasi dalam keadaan selamat dan tenang disamping menerima perkhidmatan yang lebih cekap. 


\section{Tingkahlaku selamat “altruistic”}

Tingkahlaku "altruistic" mula bertindak apabila berlaku kebimbangan terhadap keselamatan orang lain yang berlaku dalam keadaan cepat atau lambat. Tingkahlaku selamat "altruistic" timbul apabila melihat orang lain dalam keadaan terdesak atau tidak selamat sehingga ianya dapat menimbulkan rasa keinginan untuk membantu. Menurut kajian Jeffries, (1998) faktor personaliti dan persekitaran adalah penting dalam mempengaruhi sifat dan tingkahlaku "altruistic". Personaliti "altruistic" terdiri daripada pelbagai tingkahlaku baik yang terbentuk dari hasil sosialisasi. Dalam kajian ini perhatian khusus mengenai hubungan antara kesedaran risiko dan "altruistic". Sebahagian besar kajian menunjukkan bahawa tingkahlaku selamat berbeza antara lelaki dan perempuan bergantung kepada tahap risiko yang mereka rasai. Menurut kajian Belansky \& Boggiano, (1994) perempuan lebih cenderung untuk membantu rakan dalam keadaan yang tidak cemas dan tidak terancam, berbanding dengan lelaki lebih membantu orang yang mereka tidak kenali dalam keadaan cemas dan terancam. Berdasarkan teori peranan sosial dalam kajian (Eagly \& Crowley, 1986) mereka menyatakan bahawa wanita dan lelaki memberikan bantuan yang pelbagai berdasarkan skema sosial jantina mereka. Menurut teori, peranan sosial wanita memperlihatkan norma dari sifat mengambil berat sementara peranan lelaki memperlihatkan norma menunjukkan keberanian atau persaingan yang ingin ditunjukkan. Kajian mereka menunjukkan bahawa lelaki mungkin lebih membantu daripada wanita dalam situasi jangka pendek dengan orang yang tidak dikenali khususnya dalam keadaan berlakunya kecemasan.

Manusia dikurniakan mekanisme psikologi yang mengarahkan mereka memproses maklumat, membuat pilihan, dan mengeluarkan semula maklumat tersebut untuk digunakan seperti yang dinyatakan oleh Confer, Easton, Fleischman, Goetz, Lewis, Perilloux \& Buss, (2010). Sebagai contoh seseorang yang pernah terselamat dalam situasi cemas akan menggunakan semula langkah atau tindakan selamat yang pernah dilalui dalam keadaan cemas. Menurut kajian Kenrick, Griskevicius, Neuberg dan Schaller, (2010) setiap pengalaman dalam tindakan dan penyelesaian yang dialui oleh seseorang pasti berbeza-beza dan tidak sama dengan orang lain khusus dalam motif kelangsungan hidup. Tingkahlaku "altruistic" dilihat banyak dibincangkan dalam model motif perlindungan diri dimana manusia sering menghadapi potensi kemungkinan diancam bahaya dari manusia dan juga persekitaran yang tidak selamat sebagai contoh perasaan takut dalam keadaan gelap (Schaller, Park, \& Mueller, 2003). Menurut Neuberg, Kenrick dan Schaller, (2011) dalam kehidupan manusia telah mengembangkan satu mekanisma tingkah laku yang membolehkan mereka melindungi diri mereka. Sebagai contoh, melihat ular di dalam hutan boleh mendorong individu untuk melindungi diri sendiri dengan mengambil tindakan atau keputusan unutk mengembalikan semula keadaan yang lebih selamat. Motif perlindungan diri dapat menghasilkan keperluan lain termasuk mengelakkan risiko bahaya serta kerugian yang dialami (Lerner \& Keltner, 2001; Li, Kenrick, Griskevicius \& Neuberg, 2012).

Dalam situasi sikap "altruistic" tindakan tersebut bertentangan dengan sikap mementingkan diri sendiri atau ego. Perkataan "altruistic" dicipta oleh ahli falsafah Perancis, Auguste Comte dalam bahasa Perancis, dalam sebutan egoisme. Dalam pemerhatian "altruistic" adalah individu secara moral bertanggungjawab untuk memberi manfaat kepada orang lain. Sebagai contoh menyelamatkan mangsa kemalangan tanpa mengharapkan balasan dari tindakan tersebut. Menurut kajian Steinberg (2010) mencadangkan definisi "altruistic" sebagai satu "tindakan yang sengaja untuk meningkatkan kebajikan orang lain tanpa balasan". Terdapat banyak perdebatan adakah "altruistic" benar berlaku dalam psikologi manusia atau tidak. Berdasarkan teori egoisme menunjukkan bahawa tiada kaitan dengan tindakan membantu atau berkorban tanpa mengharapakan balasan.

Menurut kajian Schachter, (1959) ketakutan dapat mendorong sikap "altruistic" untuk "bersatu bersama" menghadapi ancaman dan bahaya. Dengan anggapan ini bahawa motif perlindugan diri selari dengan tindakan tingkahlaku selamat "altruistic" dimana individu tersebut juga akan melindungi orang lain yang menghadapi situasi bahaya. Oleh itu hipotesis kajian menguji hubungan kesedaran risiko keselamatan dengan tingkahlaku keselamatan "altruistic" yang mendorong diri sendiri dan orang lain untuk berasa selamat dari ancaman. Ini menunjukkan bahawa penglibatan aktiviti rekreasi luar, memberikan kesan yang besar terhadap individu seperti menambah ilmu pengetahuan, meningkatkan kemahiran dan juga kecergasan (Noor \& Mohamad, 2002). Menurut Taff, (2011) melalui penglibatan pedidikan rekreasi luar, ia mampu meningkatkan daya tahan lasak, lebih cemerlang di dalam beroperasi dengan masyarakat. Ini jelas menunjukkan bahawa risiko penglibatan aktiviti rekreasi luar mempunyai 
kesan terhadap tingkahlaku selamat oleh individu mahupun dalam kumpulan yang melibatkan diri dalam aktiviti rekreasi. Sebagai contoh dalam kajian (Pfaff, 2008) menyatakan bahawa tekanan adalah hubungan antara situasi dan kemampuan diri untuk bertindak balas dalam memenuhi tunturan tekanan tersebut. Dalam rekreasi, peserta akan mengalami kerisauan apabila berhadapan dengan risiko bahaya yang mengatasi keupayaan mereka.

Hasil daripada pengalaman situasi berisiko yang diperolehi seseorang individu boleh dipertingkatkan lagi dengan pelaksanaan proses refleksi ke atas pengalaman yang telah diperolehi daripada aktiviti yang dilakukan. Ini boleh dikaitkan dengan teori Kolb \& Schon yang mana seseorang boleh membuat refleksi ketika memerhati, bertindak, merasai dan berfikir khususnya apabila mereka melalui aktiviti rekreasi tersebut. Menurut Schon, (2017) beliau mengemukakan konsep refleksi dalam tindakan dan refleksi atas tindakan, sebagai contoh, ketika melakukan aktiviti rekreasi dengan jurulatih, seseorang sentiasa dinasihati untuk mematuhi peraturan agar aktiviti dapat dilaksanakan dengan selamat. Jika individu tersebut berfikir dan membuat refleksi bahawa mematuhi peraturan adalah satu tingkahlaku "altruistic" yang selamat dan menguntungkan, maka dia akan mengulangi tingkahlaku "altruistic" tersebut terhadap orang dan pesekitaran yang lain. Menurut Ismail, Soaib, Shamsudin dan Shafie, (2014) keadaan pengalaman ini perlu berlaku lebih banyak untuk menjadi satu tabiat dalam tindakan seseorang.

\section{Tujuan dan hipotesis kajian}

Tujuan kajian ini dijalankan adalah untuk mengenalpasti dan membandingkan kesedaran risiko dan tingkahlaku selamat peserta dalam pelaksanaan aktiviti rekreasi Bina Insan Guru. Selain itu, kajian ini turut mengenalpasti hubungan antara kesedaran risiko dengan tingkahlaku selamat. Berikut ialah hipotesis kajian:

Ho1: Tidak terdapat perbezaan yang signifikan antara kesedaran risiko berdasarkan jantina peserta.

Ho2: Tidak terdapat perbezaan yang signifikan di antara tingkahlaku selamat berdasarkan jantina peserta.

Ho3: Tidak terdapat hubungan yang signifikan antara kesedaran risiko dengan tingkahlaku selamat.

\section{METODOLOGI}

\section{Rekabentuk kajian}

Kajian dijalankan adalah secara tinjauan dengan mengedarkan borang soal selidk sepenuhnya. Kaedah tinjauan dipilih kerana kaedah tinjauan bersesuaian dengan bilangan sampel yang ramai dan dapat menjimatkan masa dan tenaga berbanding dengan kaedah kualitatif (Konting, 2005). Kaedah soal selidik juga dapat mengurangkan ralat penghitung dan membolehkan jawapan responden dibandingkan. Kajian ini melihat dua pembolehubah iaitu kesedaran risiko dan tingkahlaku selamat.

\section{Populasi dan Sampel kajian}

Populasi kajian terdiri daripada pelajar-pelajar tahun akhir jurusan Ijazah Sarjana Muda Pendidikan, Fakulti Pendidikan di Kolej Universiti Islam Antarabangsa Selangor (KUIS). Responden dipilih secara rawak bertujuan dengan hanya memilih 81 orang pelajar bagi satu sesi program latihan bina insan guru sebagai responden kajian. Persampelan bertujuan bermakna persampelan tidak mewakili populasi tetapi dapat memberikan gambaran awal mengenai bidang kajian. Pemilihan peserta kajian tinjauan (sampel pelajar) adalah berbentuk pensampelan bertujuan atau "purposive sampling" bagi memastikan maklumat yang diperoleh dapat memberi jawapan kepada persoalan kajian. Menurut Chua, (2006), 
persampelan bertujuan merujuk kepada prosedur persampelan iaitu sekumpulan subjek yang mempunyai ciri-ciri tertentu sahaja dipilih dengan sengaja (dengan niat) sebagai responden kajian berdasarkan pengetahuan dan tujuan khusus penyelidikan pengkaji.

\section{Instrumen Kajian}

Instrumen kajian yang digunakan ialah satu set soal selidik yang dibahagi kepada dua bahagian, iaitu Bahagian A dan B. Bahagian A berkaitan maklumat biodata pelajar. Bahagian B berkaitan dua pembolehubah persepsi terhadap peraturan keselamatan dan tingkahlaku selamat serta soal selidik ini mengandungi 12 soalan. Kajian rintis telah dijalankan menggunakan program Statistical Package for Sosial Sciences (SPSS) versi 20.0. Hasil analisis menunjukkan nilai Alpha Cronbach $(\alpha)$ purata bagi item-item yang terlibat. Nilai pekali kebolehpercayaan bagi soal selidik ialah 0.723.

\section{Prosedur}

Semua data dan maklumat kajian dimasukkan dan dianalisis dengan menggunakan perisian Statistical Package for Sosial Science (SPSS Windows versi 20.0) untuk memperoleh statistik deskriptif seperti kekerapan, peratus, min dan sisihan piawai, graf bar dan statistik inferensi, dan pekali korelasi Pearson bagi demografi subjek. Interprestasi min berdasarkan skala Mohammed Sani (1999), iaitu 4.00 hingga 5.00 (tahap tinggi), 3.00 hingga 3.99 (tahap sederhana) dan 1.00 hingga 2.99 (tahap rendah). Statistik inferensi pula digunakan untuk menganalisis data bagi menguji hipotesis kajian. Aras keyakinan 95 peratus $(\mathrm{p}<0.05)$ digunakan untuk menentukan aras kesignifikanan statistik. Manakala pekali Korelasi Pearson digunakan untuk mengukur dan menilai hubungan antara dua atau lebih pemboleh ubah. Nilai pekali korelasi ini antara -1 hingga +1 menunjukkan tiga kemungkinan hubungan, iaitu hubungan positif, hubungan negatif atau tiada hubungan $(\mathrm{r}=0)$. Tanda $(+)$ atau $(-)$ masing-masing menjelaskan arah hubungan yang positif atau negatif, manakala nilai mutlaknya pula menjelaskan kekuatan hubungan. Bagaimanapun, pekali korelasi Pearson tidak boleh digunakan untuk membuat inferensi tentang sebab dan akibat, kerana kajian korelasi tidak bertujuan untuk membuktikan sebab dan akibat (Baba, 1997). Dalam kajian ini, pekali korelasi Pearson digunakan untuk menjelaskan arah dan kekuatan hubungan antara kesedaran risiko dengan tingkahlaku keselamatan peserta BIG.

\section{DAPATAN KAJIAN \& PERBINCANGAN}

Jadual 1. Ujian-t tahap kesedaran risiko aspek (peratusan keselamatan) yang dialami oleh peserta BIG mengikut jantina

\begin{tabular}{lcccc}
\hline Jantina & Bil & Min & T & sig \\
\hline Lelaki & 21 & 4.555 & -1.590 & 0.11 \\
Perempuan & 60 & 4.733 & & \\
\hline
\end{tabular}

Berdasarkan Jadual 1 didapati nilai-t bagi perbandingan tahap kesedaran risiko antara peserta lelaki dan perempuan adalah $\mathrm{t}=-1.590$ dan tahap signifikan $\mathrm{p}=0.11$. Tahap signifikan ini lebih besar daripada $0.05(\mathrm{p}=0.11>0.05)$. Oleh itu, tidak terdapat perbezaan yang signifikan dalam tahap kesedaran risiko antara peserta lelaki dan perempuan dalam aktiviti rekreasi BIG. IIni bermakna Hipotesis null diterima.

Daripada dapatan menunjukkan bahawa peserta peka terhadap situasi keselamatan yang telah dilaksanakan oleh pihak pengurus tempat rekreasi tersebut. Dapatan ini selari dengan kajian Hamid dan Ahmad, (2012) yang menyatakan bahawa tiada perbezaan dalam tahap kesedaran risiko antara lelaki dan perempuan. Peserta menunjukkan kesedaran terhadap aktiviti rekreasi melalui penglibatan aktiviti rekreasi luar dimana dapat memberikan kesan yang positif terhadap individu seperti menambah ilmu pengetahuan, meningkatkan kemahiran dan juga kecergasan (Noor \& Mohamad, 2002). Kesedaran keselamatan melalui aktiviti berisiko penting terutama melibatkan kesan kecederaan. Oleh itu peserta dapat memberi tanggapan yang selari dengan pandangan dalam kajian (Holt, 2005) yang menyatakan 
bahawa keselamatan adalah satu keadaan sifar bahaya, tiada peluang yang boleh mewujudkan suasana bahaya ditempat rekreasi tersebut.

Jadual 2. Ujian-t tahap tingkahlaku keselamatan yang dialami oleh peserta BIG mengikut jantina

\begin{tabular}{lllll}
\hline Jantina & Bil & Min & t & sig \\
\hline Lelaki & 21 & 4.547 & -0.179 & 0.859 \\
Perempuan & 60 & 4.575 & & \\
\hline
\end{tabular}

Berdasarkan Jadual 2 didapati nilai-t bagi perbandingan tahap tingkahlaku keselamatan antara peserta lelaki dan perempuan adalah $\mathrm{t}=-0.179$ dan tahap signifikan $\mathrm{p}=.859$. Tahap signifikan ini lebih besar daripada $0.05(\mathrm{p}=0.859>0.05)$. Oleh itu, tidak terdapat perbezaan yang signifikan tahap tingkahlaku keselamatan antara peserta lelaki dan perempuan dalam aktiviti rekreasi BIG. Ini bermakna hipotesis null diterima.

Keseluruhan perseta menunjukkan sikap berhati-hati dan selamat ketika menjalankan aktiviti rekreasi. Tingkahlaku "altruistic" mula membentuk apabila berlaku kebimbangan terhadap keselamatan orang lain berlaku. Tingkahlaku selamat "altruistic" berlaku apabila melihat orang lain dalam keadaan terdesak dan menimbulkan rasa keinginan untuk membantu. Menurut Jeffries, (1998) menyatakan bahawa faktor personaliti dan persekitaran adalah penting dalam mempengaruhi sifat dan tingkahlaku "altruistic".

Jadual 3. Korelasi di antara Kesedaran risiko dengan tingkahlaku keselamatan

\begin{tabular}{lcc}
\hline & Peraturan keselamtan & Tingkahlaku keselamatan \\
\cline { 2 - 3 } Pearson Correlation & 1 & $.353^{* *}$ \\
Sig. (2-tailed) & & .001 \\
$\mathrm{~N}$ & 81 & \\
\hline
\end{tabular}

Hasil daripada analisa korelasi dalam jadual 3 menunjukkan bahawa terdapat hubungan yang signifikan positif di antara kedua pembolehubah iaitu kesedaran risiko (Peraturan keselamatan) dengan tingkahlaku keselamatan. Korelasi di antara kesedaran risiko (Peraturan keselamatan) dengan tingkahlaku keselamatan adalah signifikan $(\mathrm{r}=.353 ; \mathrm{p}=0.001, \mathrm{p}<.05)$. Berdasarkan hasil ujian interkorelasi, nilai $r=.353$ menunjukkan korelasi positif yang sederhana antara aspek peraturan keselamatan dan tingkahlaku keselamatan. Ujian korelasi ini menunjukkan nilai signifikan pada $p<.01$. Ini bermakna hipotesis nul ketiga ditolak. Hasil kajian ini menunjukkan bahawa terdapat hubungan di antara kesedaran risiko (peraturan keselamatan) dengan tingkahlaku keselamatan.

Daripada dapatan menunjukkan bahawa terdapat hubungan antara kesedaran risiko dengan tingkahlaku keselamatan altruistic oleh peserta BIG. Menurut Schachter, (1959) ketakutan dapat mendorong sikap altruistic untuk "bersatu bersama" menghadapi ancaman dan bahaya. Dengan anggapan ini bahawa motif perlindugan diri selari dengan tindakan tingkahlaku selamat "altruistic" dimana individu tersebut juga akan melindungi orang lain yang menghadapi situasi bahaya. Oleh itu hipotesis kajian menguji hubungan kesedaran risiko keselamatan dengan tingkahlaku keselamatan "altruistic" yang mendorong diri sendiri dan orang lain untuk selamat dari ancaman. Ini menunjukkan bahawa penglibatan aktiviti rekreasi luar, memberikan kesan yang besar terhadap individu seperti menambah ilmu pengetahuan, meningkatkan kemahiran dan juga kecergasan (Noor \& Mohamad, 2002). Aktiviti rekreasi yang berisiko juga dapat meningkatkan motivasi dan keyakinan diri. Menurut Shank dan Lyberger (2009) menyatakan bahawa motivasi telah ditaktifkan sebagai satu kesan dalaman yang menghasilkan tingkahlaku ke arah memenuhi keperluan. Sebagai contoh motivasi penglibatan kanak-kanak sejak kecik merupakan satu faktor penting untuk meramal penglibatan sukan dan rekreasi dalam kalangan kanak-kanak (Vallerand, Deci \& Ryan, 1987). Ibu bapa perlu memandang secara positif 
penglibatan sukan dan rekreasi serta memahami kesan yang diperolehi kepada anak-anak dari sudut intrinsik dan ekstrinsik. Merujuk kepada teori tersebut memperlihatkan bahawa individu yang bermotivasi akan lebih mengalami kognitif, afektif dan tingkah laku positif (Deci \& Ryan, 2000).

\section{KESIMPULAN \& CADANGAN}

Amalan pengurusan risiko yang telah dikenal pasti hasil daripada kajian ini dapat membantu pihak pengurus aktiviti rekreasi melaksanakan prosedur keselamatan dalam pengurusan risiko ditempat rekreasi. Pihak pengurus rekreasi juga boleh merangka kursus atau latihan dalam perkhidmatan dengan mengundang pakar yang boleh memberikan bimbingan dan informasi pengurusan risiko yang diperlukan. Sehubungan ini, dicadangkan melalui persatuan rekreasi, pengurusan pihak jabatan awam boleh merangka kursus dan taklimat dengan mengundang pakar pengurusan risiko yang dapat memberikan bimbingan dan informasi penting yang diperlukan oleh pengurus rekreasi, peserta dan masyarakat.

Perkembangan teknologi maklumat termasuk media yang menyiarkan pelbagai program aktiviti rekreasi yang terkini dari negara-negara maju seharusnya membuka minda masyarakat tentang cara sesuatu program rekreasi sifar risiko boleh dilaksanakan dengan begitu profesional oleh jurulatih atau pengurus yang kompeten dalam pengurusan risiko ditempat rekerasi. Dengan ini, dicadangkan masyarakat umum khasnya ibu bapa kepada pelajar-pelajar yang kerap terlibat dalam aktiviti dan program rekreasi, seharusnya lebih peka dan perlu proaktif untuk mengambil tahu penglibatan programprogram keselamatan yang wujud. Ibu bapa juga perlu bersifat pemilih dan hanya membenarkan/mengizinkan anak-anak jagaan mereka menyertai program rekreasi yang terancang, terjamin bebas risiko, berfaedah dan hanya dikendalikan oleh jurulatih yang berkelayakan dan kompeten dalam pengurusan risiko. Masyarakat dan ibu bapa boleh juga menjadi kumpulan pendesak dan pemerhati kepada program rekreasi bersifat sifar risiko melalui persatuan ibu bapa atau NGO.

Hasil dan dapatan kajian ini berguna kepada para guru, jurulatih, pensyarah, penyelidik dan semua pihak yang ingin menjalankan kajian lanjutan. Bagi tujuan peluasaan dan pelanjutan dalam bidang penyelidikan, beberapa cadangan yang berikut dikemukakan dimana kajian ini tertumpu kepada hubungan risiko kalangan peserta normal BIG dengan tingkahlaku selamat. Di dalam aktiviti rekreasi terdapat aktiviti bagi individu keperluan khas, dan untuk itu dicadangkan supaya dikaji amalan pengurusan risiko bagi rekreasi individu keperluan khas. Seterusnya kajian perlu dijalankan terhadap keberkesanan kerangka model amalan pengurusan risiko bagi jurulatih rekreasi daerah atau negeri yang telah dibangunkan hasil daripada kajian ini dengan melibatkan pendapat jurulatih atau pengurus rekreasi. Kajian yang lebih terperinci perlu dijalankan merangkumi faktor penyumbang luaran yang lain seperti faktor motivasi atau dorongan, ekonomi, politik dan sosial bagi mendapatkan pengaruh dan kesannya terhadap pengurusan rsiko aktiviti rekreasi.

\section{RUJUKAN}

Baba, A. (1997). Statistik Penyelidikan dalam Pendidikan Sains Sosial. Bangi: Penerbit Universiti Kebangsaan Malaysia.

Belansky, E. S., \& Boggiano, A. K. (1994). Predicting helping behaviors: The role of gender and instrumental/expressive self-schemata. Sex Roles, 30(9-10), 647-661.

Chua, Y. P. (2006). Kaedah Penyelidikan-Kaedah dan Statistik Penyelidikan-Buku 1.

Confer, J. C., Easton, J. A., Fleischman, D. S., Goetz, C. D., Lewis, D. M., Perilloux, C., \& Buss, D. M. (2010). Evolutionary psychology: Controversies, questions, prospects, and limitations. American Psychologist, 65(2), 110.

Deci, E. L., \& Ryan, R. M. (2000). The" what" and" why" of goal pursuits: Human needs and the selfdetermination of behavior. Psychological Inquiry, 11(4), 227-268.

Eagly, A. H., \& Crowley, M. (1986). Gender and helping behavior: A meta-analytic review of the social psychological literature. Psychological Bulletin, 100(3), 283.

Hamid, M., Z., \& Ahmad, M., F. (2012). Tahap kesedaran staf UTM terhadap keselamatan pekerjaan di makmal dan bengkel kejuruteraan. Journal of Education Management, 6, 36-51 
Holt, A. S. J., \& Lampl, F. (2005). Principles of construction safety. London: Blackwell Science.

Ismail, M., Soaib, A., Shamsudin, A., \& Shafie, M., Daud. (2014). Mentor's role in human teacher development program. Jurnal Personalia Pelajar, 17.

Jeffries, V. (1998). Virtue and the altruistic personality. Sociological Perspectives, 41(1), 151-166.

Kenrick, D. T., Griskevicius, V., Neuberg, S. L., \& Schaller, M. (2010). Renovating the pyramid of needs: Contemporary extensions built upon ancient foundations. Perspectives on Psychological Science, 5(3), 292-314.

Konting, M. M. (2005). Kaedah penyelidikan pendidikan. Dewan Bahasa dan Pustaka.

Lerner, J. S., \& Keltner, D. (2001). Fear, anger, and risk. Journal of Personality and Social Psychology, 81(1), 146.

Li, Y. J., Kenrick, D. T., Griskevicius, V., \& Neuberg, S. L. (2012). Economic decision biases and fundamental motivations: How mating and self-protection alter loss aversion. Journal of Personality and Social Psychology, 102(3), 550.

Neuberg, S. L., Kenrick, D. T., \& Schaller, M. (2011). Human threat management systems: Selfprotection and disease avoidance. Neuroscience \& Biobehavioral Reviews, 35(4), 1042-1051.

Noor, M. A. M., \& Mohamad, S. S. (2002). Faktor Di Antara Motivasi Intrinsik Dan Ekstrinsik Ke Atas Penglibatan Para Pelajar Terhadap Aktiviti Pendidikan Luar-Satu Kajian Kes. Fakulti Pendidikan, Universiti Teknologi Malaysia.

Pfaff, M. S. (2008). Effects of mood and stress on group communication and performance in a simulated task environment. Doctoral Dissertation, The Pennsylvania State University, US.

Schachter, S. (1959). The psychology of affiliation: Experimental studies of the sources of gregariousness. The American Journal of Psychology, 72(2), 324. doi: 10.2307/1419397

Schaller, M., Park, J. H., \& Mueller, A. (2003). Fear of the dark: Interactive effects of beliefs about danger and ambient darkness on ethnic stereotypes. Personality and Social Psychology Bulletin, 29(5), 637-649.

Schon, D. A. (2017). The reflective practitioner: How professionals think in action. Routledge.

Shank, M. D., \& Lyberger, M. R. (2009). Sports marketing: A strategic perspective. Routledge.

Steinberg, D. (2010). Altruism in medicine: its definition, nature, and dilemmas. Cambridge Quarterly of Healthcare Ethics, 19(2), 249-257.

Taff, M. A. M. (2011). Kerelevanan Pendidikan Luar Dalam Sistem Pendidikan Tinggi Di Malaysia. Asean Journal of Teaching and Learning in Higher Education (AJTLHE), 3(1), 11 27.

Tourism BC. (2013). 2009/2010 Outdoor recreation study. [PDF] Retrieved from: http://www.destinationbc.ca/getattachment/Research/Research-by-Activity/All-Research-byActivity/Outdoor-Recreation-Study-2009-2010,-January-2013/Outdoor-Recreation-forDistribution-14Jan13-FINAL-DRAFT-(2).pdf.aspx

Tourism, A. (2014). Global Report on Adventure Tourism.

Tribe, J. (2011). The economics of recreation, leisure and tourism. Routledge.

Vallerand, R. J., Deci, E. L., \& Ryan, R. M. (1987). 12 intrinsic motivation in sport. Exercise and Sport Sciences Reviews, 15(1), 389-426.

Zakaria, J., Harun, M. T., Salamuddin, N., \& Taff, M. A. M. (2016). Risk Management Practices towards Developments of Sport and Recreational Activities in Malaysia. Open Access Library Journal, 3(07), 1.

\section{Adli Mohd Sidi}

Universiti Tun Abdul Razak

Malaysia

Email: adli@unirazak.edu.my 